\title{
Synuclein Family
}

National Cancer Institute

\section{Source}

National Cancer Institute. Synuclein Family. NCI Thesaurus. Code C21217.

Small, soluble Synuclein Family proteins are a group of highly conserved post-

transcriptionally modified Alpha, Beta, and Gamma proteins expressed primarily in neural tissue and often localized near synaptic vesicles. Synucleins may inhibit PLD2 and regulate vesicular transport. In the $\mathrm{N}$-terminal portion, synucleins have a conserved repeated 11residue amphipathic alpha-helical motif similar to the lipid-binding A2 domain of apolipoproteins. Synucleins also contain several repeated variations of a highly conserved KT KEGV domain, also present in rho family proteins. In brain, synucleins may be phosphorylated by $\mathrm{Ca} 2+$ calmodulin protein kinase II. Synucleins are overexpressed in breast carcinomas and mutations are associated with neurodegenerative illnesses. 